ZOOLOGIA 27 (6): 909-917, December, 2010

doi: $10.1590 /$ S1984-46702010000600012

\title{
Effects of habitat and landscape characteristics on medium and large mammal species richness and composition in northern Uruguay
}

\author{
María José Andrade-Núñez ${ }^{1,2} \&$ T. Mitchell Aide
}

\author{
${ }^{1}$ Department of Biology, University of Puerto Rico. POBOX 23360, San Juan. Puerto Rico 00931. \\ ${ }^{2}$ Corresponding author. E-mail: mj_andradenunez@yahoo.com
}

\begin{abstract}
The increasing world population and demand for food and other products has accelerated the conversion of natural habitats into agricultural lands, plantations and urban areas. Changes in habitat and landscape characteristics due to land-use change can have a significant effect on species presence, abundance, and distribution. Multi-scale approaches have been used to determine the proper spatial scales at which species and communities are responding to habitat transformation. In this context, we evaluated medium and large mammal species richness and composition in gallery forest $(n=10)$, grassland $(n=10)$, and exotic tree plantation $(n=10)$ in a region where grasslands have been converted into exotic tree plantations. We quantified mammal species richness and composition with camera traps and track surveys. The composition of the mammal community was related with local habitat variables, and landscape variables measured at seven spatial scales. We found 14 mammal species in forest, 11 species in plantation, and 7 mammal species in grassland. Two species are exotics, the wild boar Sus scrofa Linnaeus, 1758 and the European hare Lepus europaeus Pallas, 1778. The most common species are the crab-eating fox Cerdocyon thous Linnaeus, 1766, the nine-banded armadillo Dasypus novemcinctus Linnaeus, 1758 and the gray brocket deer Mazama gouazoubira G. Fischer, 1814 which are generalist species. Our results showed significant differences in mammal species richness and composition among the three habitat types. Plantations can have positive and negative effects on the presence of species restricted to grasslands. Positive effects are reflected in a wider local distribution of some forest species that rarely use grassland. The most important habitat and landscape variables that influenced mammal species richness and composition were vertical structure index, canopy cover, tree species diversity, percentage of grass, and the percentage of forest and grassland at the landscape scale of $0.1 \mathrm{~km}$. We advise the following important measures for conservation of this mammal community: 1) reduce logging and cattle grazing in gallery forest, and 2) increase grassland buffer zones between plantation and forest.
\end{abstract}

KEY WORDS. Conservation; community; gallery forest; grassland; plantations.

Land-use change is one of the most important threats to biodiversity (Forman 1999, SAla et al. 2000, Turner et al. 2001, Foley et al. 2005, Millennium Ecosystem Assessment 2005, Reidsma et al. 2006). Since 1850, six million $\mathrm{km}^{2}$ of forest/woodlands and 4.7 million $\mathrm{km}^{2}$ of grassland/savannas have been converted due to global expansion of croplands (LAmBin et al. 2001). Since 1960, the increasing world population and demand for food and other products have accelerated the conversion of natural habitats into agricultural lands, plantations and urban areas (FoLEY et al. 2005, LAMBIN et al. 2001). Developing regions that have been recently incorporated into the expanding world economy have had the highest rate of land conversion (LAmBIN et al. 2001). In these regions, both forests and grasslands are threatened by selective logging and clearing for agriculture expansion, but the latter are the most threatened ecosystem, because they are the most suitable for agriculture, exotic tree plantations, and cattle ranching (Cardoso da Silva \& Bates 2002, Sala et al. 2001).
Ecological effects of land-use change on species presence, abundance, and distribution may be determined by speciesspecific characteristics (e.g. body size, mobility, food and habitat requirements) that influence their survival in a transformed habitat, and determine their scale of response to habitat transformation (Кеiтt et al. 1997). For example, the transformed habitat can be hostile (e.g. high predation) and of low quality (e.g. limited resources) for specialists and small species, which may have their dispersal further limited because natural patches may become isolated from one another, increasing the probability of local extinctions (DAiLy et al. 2003, VANDERMEer \& Carvajal 2001). By contrast, generalist and large species can use these transformed habitats for food and shelter, or traverse them looking for natural habitat areas, allowing these species to maintain viable populations in a transformed landscape (Daily et al. 2003, Vandermeer \& Carvajal 2001). As a consequence, the effects of land-use change on species will be differ- 
ent for different species, even closely related species (Holland et al. 2004, Mikusinki \& Angelstam 2004). Additionally, the type and intensity of land-use (e.g. selective logging vs. clear cutting) will directly affect habitat quality (Reidsma et al. 2006) as well as the spatial configuration of natural habitats in the landscape (Daily et al. 2003, Dauber et al. 2003, Andrén 1994). For this reason, the spatial scale at which observations are made is crucial for understanding the effect of land-use change on population dynamics and community patterns (НАвеEв et al. 2005). In addition, the scale at which species interact with the landscape varies widely (KeITT et al. 1997) and is correlated with body size and mobility of the organism (OlfF \& Ritchie 2002).

Multi-scale approaches have been used with a variety of taxa at the community and species levels, trying to understand the proper spatial scales at which populations and communities respond to habitat modification (ATAURI \& LUCIO 2001, ATTUM et al. 2008, Gorresen et al. 2005, Gotmark et al. 2008, Навеeв et al. 2007, KARLSON \& CORNELl 1998, LindENMAYER et al. 1999, RHODES et al. 2009, ZaBALA et al. 2005). At the community level, the abundance of the phyllostomid bat in the Atlantic rain forest in Paraguay was associated with landscape characteristics such as patch density, patch size and patch proximity at scales of 5 $\mathrm{km}$ radius, which probably includes all or most of the home range of the species (GORRESEN et al. 2005). In this regard, this type of analysis can be a useful tool for management and conservation activities (Gorresen et al. 2005, Zabala et al. 2005).

Using multi-scale analysis, we examined how habitat and landscape variables can affect medium and large mammal communities in a grassland region in northern Uruguay. There, most of the mammal diversity occurs in riparian (gallery) forests, and afforestation with exotic species has been the major landuse change in the last 20 years. Specifically, we 1) determined mammal species richness, and composition, among gallery forests, grasslands and plantations, and 2) correlated them with habitat and landscapes characteristics. The results of this study are useful for determining management and conservation activities to protect the mammal community. In northern Uruguay the creation of protected areas is limited because the land is privately owned and used for forestry, agriculture and cattle ranching. In such a setting, it is essential to find a balance between conservation and economic development.

\section{MATERIAL AND METHODS}

We conducted the study from January to December, 2008, in the northeastern Uruguay. There, natural habitats have been transformed for cattle grazing, agriculture and afforestation with exotic trees. Grassland occupies approximately $80 \%$ of the country, being the main ecosystem where these activities have been developed and hence the most impacted (Cracco et al. 2005). This transformation is due to the high fertility of grassland soils, easy accessibility and relatively flat topography. The area of exotic tree plantations have increased rapidly following the implementation of the Forestry Law (\# 15,939), which provided incentives and subsidies to investors that developed plantations on low fertility soils (Geary 2001). In 1987, 31,000 ha were planted primarily with Eucalyptus and Pinus spp. and by 2005 there were 766,000 ha of plantations (http:/ /faostat.fao.org, MGAP 2005). Exotic tree plantations are becoming economically important in Uruguay and it is expected that by $2020,900,000$ ha will be covered by exotic tree plantations, corresponding to $5 \%$ of the country (TORREs \& FossatI 2004). Plantations occur throughout the country, but $18.7 \%$ of all plantations occur in the department of Rivera, northern Uruguay.

The study area comprises a region of approximately 67,000 ha in the northwestern part of the department of Rivera (Fig. 1). The climate is humid subtropical, with mean temperatures of $18.1^{\circ} \mathrm{C}$ and mean annual rainfall of $1653 \mathrm{~mm}$ (COFUSA 2006). The main land-uses in the area are grassland mainly used for cattle ranching, gallery (or riparian) forest, small wetlands, watermelon and tobacco crops, exotic tree plantations and urban areas. In Rivera, 11,000 ha were planted mainly with Pinus spp. and Eucalyptus spp. in 1987, and by 2005 there were 124,382 ha of plantations (MGAP 2005).

Study sites were located in ten properties of a forestry company (Fig. 1). The properties occur in northern Rivera and the mean distance to the neighboring property was $6.68 \mathrm{~km}$. In each property, we selected a gallery forest site, a grassland site, and a plantation site, separated from one another by an average of $1 \mathrm{~km}$, for a total of 30 sites. Within each site we sampled an area of approximately $2.5 \mathrm{ha}$. Sites were selected based on accessibility, and that there were no active management activities (e.g. logging) occurring near the sites during the time of the study.

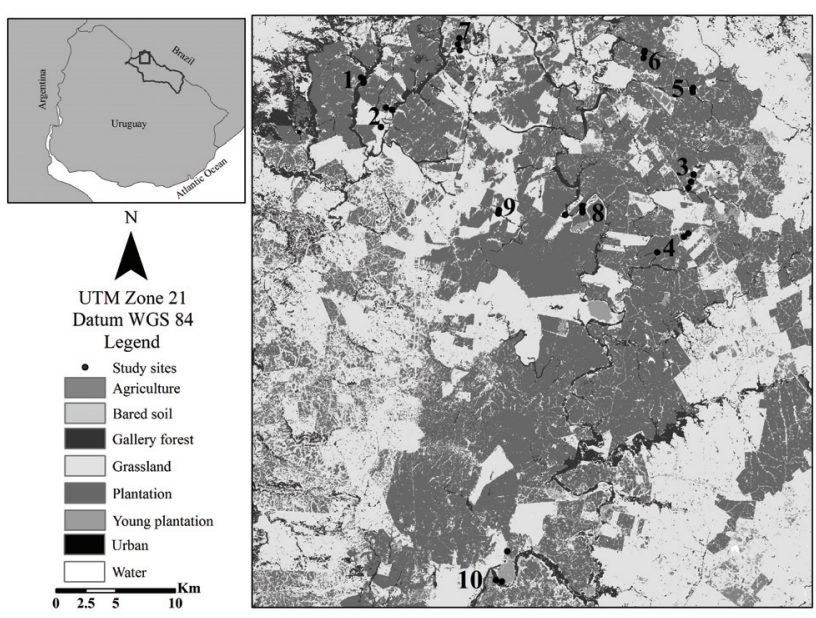

Figure 1. Map of Uruguay showing the location of the study area (red or black square) in the department of Rivera, and a land-use map showing the ten forestry company properties where a forest, a plantation and a grassland site were surveyed. 
Gallery forest sites are characterized by a predominance of small trees (e.g. Sebastiania commersioniana (Baill.) L. B. Sm \& Downs, Sebastiania brasiliensis Spreng., Eugenia uniflora L., Lithraea molleoides (Vell.) Engl, Scutia buxifolia Reissek and Allophyllus edulis (A. St.-Hil.) Radlk.) and shrub species (e.g. Daphnosis racemosa Griseb, 1879). The canopy is closed with an understory density that varies from dense to sparse depending on the presence of cattle which feed on seedlings and create small trails inside the forest, preventing seedlings from growing. All plantations were monocultures of Eucalyptus spp. and are actively managed. Plantation sites varied in age from 2 to 18 years old. Young plantation sites are characterized by small Eucalyptus trees (e.g. 4-6 m tall), an open canopy, and an understory with bare ground or a low grass cover. Older plantations are characterized by large Eucalyptus trees (e.g. 16-25 m tall), a close canopy, and an open understory dominated by branches and bark. In some sites, there were a few small native shrubs or trees, or Eucalyptus. Grassland sites were characterized by a predominance of grasses and herbaceous vegetation and a lack of trees and shrubs species.

We quantified mammal species richness and composition in the 30 sites in three surveys. The first survey was carried out from January to April, 2008, the second survey from June to August, 2008, and the third survey from September to December, 2008. Each site was surveyed for approximately 24 days. In each survey, we conducted direct and indirect methods to detect mammals. The direct method consisted of four digital camera traps (Cuddeback Excite Digital Camera, 2 Megapixels) for eight consecutive days in each site for a total of 96 camera/days per site ( 3 censuses $\mathrm{x} 4$ cameras $\mathrm{x} 8$ days). Camera traps were separated on average by $60 \mathrm{~m}$ and were tied to a tree or placed on an iron bar at $50 \mathrm{~cm}$ above the ground. We placed camera traps in sites where the probability of mammal detection was high (e.g. near rivers, ponds, trails, dens) and we changed the position of the camera traps in each survey. We used apples, bananas, sardines and vanilla as baits. In addition to camera traps, we conducted walking censuses for tracks, scats, dens and direct observations of animals. In each site, we conducted two walking censuses for 30 minutes each during each of the three surveys for a total of 3 hours.

Habitat measurements were collected from January to April 2008. In each site, a 5 x $50 \mathrm{~m}$ transect was established and the diameter at breast height (DBH) was measured for trees $>10 \mathrm{~cm} \mathrm{DBH}$. Trees and shrubs between 1-10 cm DBH were sampled in a $1 \times 50 \mathrm{~m}$ transect. These data were used to calculate stand basal area $\left(\mathrm{m}^{2} / \mathrm{ha}\right)$ and tree density (number of trees/ ha). We identified each tree and shrub to species or morphospecies. Tree diversity was calculated using ShannonWiener index. For each tree, the height of the first branch was recorded. Ground cover was measured every $5 \mathrm{~m}$ along the 50 $\mathrm{m}$ transect, within a $1 \mathrm{x} 1 \mathrm{~m}$ plot, by estimating the percent of the plot occupied by trees, shrubs, grass, leaf litter, bark, fallen branches and bared soil. Leaf litter depth was measured three times within each plot. Vegetation structure was estimated by determining the presence or absence of vegetation within different height ranges $(\mathrm{m})$ (e.g. $0-2,2-4 \ldots>30 \mathrm{~m}$ ). With these data we calculated habitat vertical structure heterogeneity using a Shannon-Wiener diversity index (from now vertical structure index). Higher values of the index represent a complex structural habitat. Percent canopy cover was measured using an ocular tube every $5 \mathrm{~m}$. Additionally, temperature and relative humidity were measured during each survey using sensors (Hobo Pro v2 Part \# U23-001) located at $50 \mathrm{~cm}$ above ground. The width of water courses associated with gallery forests was measured. To estimate the potential impact of cattle, horses and sheep on the mammal community we calculated an index by dividing the number of photos of these animals by the number of days of observations.

Using a land-use map of the study region we calculated the area of each land-use classes within seven buffer areas around each site with the following radiuses: $0.1,0.5,1,1.5,2$, 3 and $4 \mathrm{~km}$, using ArcGis 9.2. We selected buffer radiuses in relation to the home range sizes of the species registered during the survey (IUCN 2008). This procedure allowed us to determine the extent of the landscape analysis appropriate for this community of mammals. For the landscape variables, we used the percent area of each land-use class because the total area of different habitats tends to be more important than habitat fragmentation for the viability of wildlife populations (FAHRIG 2003).

We calculated mammal species richness using incidence data from track and camera surveys for each habitat type (plantation, gallery forest and grassland) using sample-based rarefaction curves (species accumulation curves). We performed species accumulation curves using Mao Tau estimator with confidence intervals set at 95\% (Gotelli \& Colwell 2001). We generated Mao Tau analytical estimator as well as other parametric and non-parametric estimators by performing 100 randomizations without replacement using EstimateS 7.5.1 (Colwell 2005). We generated different species richness estimators to determine if the sampling effort was enough to achieve a confident result of species richness.

We used a Multi-Response Permutation Procedure (MRPP), based on Sorensen (Bray-Curtis) distance, with incidence (i.e. presence/absence) mammal data to test for significant difference in assemblage composition between forest, plantation and grassland habitats. We applied a Bonferroni correction to the pair-wise $p$-values (i.e., individual $p<0.05 /$ number of comparisons were considered significant) to maintain the overall alpha level of 0.05 and avoid type I error (Holm 1979).

We performed Kruskall-Wallis test to determine if mammal species richness among sites was different. In addition, we performed Nonmetric multidimensional scaling (NMS) method with incidence data as the main matrix and habitat and landscape variables (i.e. environmental variables) as the second matrix to determine if mammal composition between habitats 
was different and to determine which habitat and landscape variables were correlated with mammal species richness and composition in each site. For the NMS, the second matrix was relativized by each column (i.e. each environmental variable) maximum. We used Sorensen (Bray-Curtis) distance measure. We performed a first run with six axes stepping down in dimensionality, 50 runs with real data, stability criterion $=0.0005$ and the iterations to evaluate stability in 200 (Monte Carlo tests), we set the initial step length to 0.20 and selected random numbers for the starting coordinates. This first run was performed to determine the number of dimensions of the ordination and the starting configuration for the final run. For the final run the percent of correlation with distance matrix $\left(r^{2}\right)$ was calculated to evaluate the efficiency of the ordination distance to represent the distances in the real data and to determine the two axes that explained most of the ordination space which were the ones used to graphic representation. MRPP and NMS analysis were performed using PcOrd 5.0 (MCCune \& MefFord 1999). Kruskall-Wallis test was performed using R 2.9 (R Development Core Team 2009).

\section{RESULTS}

\section{Mammal species survey and sampling effort}

Fifteen species of medium and large mammals were recorded with approximately 960 camera/days (240 days x 4 camera traps) and 30 hours of walking census per habitat type. We found 14 mammal species in forest sites, 11 species in planta- tion sites, and 7 mammal species in grassland sites. Two of these species are exotics, the wild boar Sus scrofa Linnaeus, 1758 and the European hare Lepus europaeus Pallas, 1778 and are considered invasive in Uruguay (Tab. I). The most abundant species were the crab-eating fox Cerdocyon thous Linnaeus, 1766, the nine-banded armadillo Dasypus novemcinctus Linnaeus, 1758 and the gray brocket deer Mazama gouazoubira G. Fischer, 1814 which were recorded in almost every site and in the three habitat types (Tab. I). Rare species included the margay Leopardus wiedii Schinz, 1821 recorded in a single photograph at a forest site and the lesser grison Galictus cuja Molina, 1782 which was recorded in two forest sites by tracks (Tab. I). The number of species observed in the three habitats was similar to the expected values predicted by most of the species richness estimators (Tab. II). At a regional scale the sampling effort was enough to confidently estimate species richness. The rarefaction curve analysis suggests that 150 sample days are needed to determine mammal species richness in grassland and 240 days in forest and plantation.

\section{Mammal species richness, and composition in forests, plantations, and grasslands}

Forest, plantation, and grassland differed in mammal species richness ( $\mathrm{KW}=15.08, \mathrm{df}=2, \mathrm{p}<0.001$ ) (Fig. 2). Forest was the most diverse habitat (mean $=7$ ) followed by plantation $($ mean $=4$ ) and grassland (mean $=3$ ). There was no significant difference in species richness between plantation and grassland.

Table I. Number of filtered photos, tracks, scats and direct observations (Obs.) of medium and large mammal species, and the number of sites where a species was recorded. Filtered photos = number of photos determined by assuming that multiple photographs of a species (or a pair or group in the case of foxes and wild boars, respectively) taken by a single camera during any 24-hours period represented a single individual (SANDERSON 2004). * Exotic species.

\begin{tabular}{|c|c|c|c|c|c|c|c|c|c|c|c|}
\hline \multirow{2}{*}{ Family } & \multirow{2}{*}{ Species } & \multicolumn{3}{|c|}{ Forest $(n=10)$} & \multicolumn{3}{|c|}{ Plantation $(n=10)$} & \multicolumn{3}{|c|}{ Grassland $(n=10)$} & \multirow{2}{*}{ Total records } \\
\hline & & Photos & Obs. & Sites & Photos & Obs. & Sites & Photos & Obs. & Sites & \\
\hline Canidae & Cerdocyon thous & 86 & 16 & 10 & 42 & 6 & 10 & 21 & 2 & 7 & 173 \\
\hline Dasypodidae & Dasypus novemcinctus & 53 & 28 & 10 & 11 & 7 & 6 & 4 & 5 & 5 & 108 \\
\hline Cervidae & Mazama gouazoubira & 24 & 38 & 10 & 15 & 15 & 10 & 3 & 11 & 5 & 106 \\
\hline Canidae & Pseudalopex gymnocercus & 15 & 2 & 2 & 11 & 4 & 2 & 5 & 0 & 2 & 37 \\
\hline Mustelidae & Conepatus chinga & 6 & 6 & 8 & 9 & 2 & 5 & 6 & 1 & 6 & 30 \\
\hline Leporidae & Lepus europaeus * & 0 & 0 & 0 & 7 & 8 & 5 & 1 & 3 & 4 & 19 \\
\hline Felidae & Oncifelis geoffroyi & 15 & 1 & 7 & 2 & 0 & 1 & 0 & 0 & 0 & 18 \\
\hline Procyonidae & Procyon cancrivorous & 6 & 8 & 8 & 0 & 1 & 1 & 0 & 0 & 0 & 15 \\
\hline Hydrochaeridae & Hydrochoerus hydrochaeris & 2 & 11 & 4 & 0 & 0 & 0 & 0 & 0 & 0 & 13 \\
\hline Suidae & Sus scrofa * & 2 & 2 & 3 & 1 & 0 & 1 & 1 & 4 & 2 & 11 \\
\hline Dasypodidae & Euphractus sexcinctus & 2 & 0 & 1 & 3 & 2 & 1 & 0 & 0 & 0 & 7 \\
\hline Mustelidae & Lontra longicaudis & 1 & 5 & 4 & 0 & 0 & 0 & 0 & 0 & 0 & 6 \\
\hline Didelphidae & Didelphis albiventris & 2 & 1 & 2 & 2 & 0 & 1 & 0 & 0 & 0 & 5 \\
\hline Mustelidae & Galictis cuja & 0 & 2 & 2 & 0 & 0 & 0 & 0 & 0 & 0 & 2 \\
\hline Felidae & Leopardus wiedii & 1 & 0 & 1 & 0 & 0 & 0 & 0 & 0 & 0 & 1 \\
\hline
\end{tabular}

ZOOLOGIA 27 (6): 909-917, December, 2010 
Table II. Results of different species richness estimators for the number of mammal species in the study area. (Mao Tau) Observed species richness, (ACE) Abundance-base Coverage Estimator, (Chao 1; Jack1) First-order Jackniffe richness estimator, (Bootstrap; MMMeans) Michaelis-Menten richness estimator.

\begin{tabular}{lccc}
\hline \multicolumn{1}{c}{ Estimators } & Forest & Plantation & Grassland \\
\hline Mao Tau & 14 & 11 & 7 \\
ACE & 14 & 12 & 7 \\
Chao 1 & 14 & 11 & 7 \\
Jack 1 & 15 & 12 & 7 \\
Bootstrap & 15 & 12 & 7 \\
MMMean & 14 & 12 & 8 \\
\hline
\end{tabular}

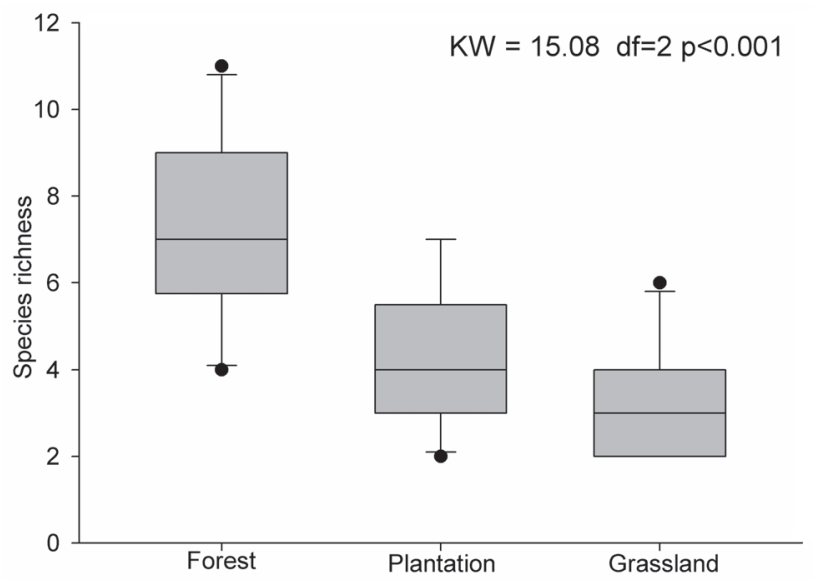

Figure 2. Differences in mammal species richness among forest, grassland and plantation sites.

The NMS ordination using incidence data extracted two axes that explain $72 \%$ of the total variance (Fig. 3). The presence of five mammal species had the highest correlation values with the ordination, and had the strongest influence in determining the ordination. The geoffroy's cat Oncifelis geoffroyi d'Orbign \& Gervais, $1844(\mathrm{r}=0.681)$, the crab-eating raccoon Procyon cancrivorus Cuvier, $1798(\mathrm{r}=0.629)$, and M. gouazoubira $(\mathrm{r}=0.624)$, were positively correlated with axes $1 . D$. novemcinctus $(\mathrm{r}=-0.757)$ and the hog nosed skunk Conepatus chinga Molina, $1782(\mathrm{r}=-0.657)$ were negatively correlated with axes 2 . One forest site is separated from the rest of the forest because it had two species (the white-eared opossum Didelphis albiventris Lund, 1840 and the yellow armadillo Euphractus sexcinctus Linnaeus, 1756) that were not found in the other forest sites. Two grassland sites that shared one species, M. gouazoubira, were separated from the remaining because they had only two species. Mammal species composition, using incidence data between forest and grassland and between forest and plantation sites was significantly different using Bonferroni correction $(p<0.0166)$
(MRPP, $\mathrm{A}=0.13, \mathrm{p}<0.001 ; \mathrm{A}=0.153 \mathrm{p}<0.001$ respectively). Several species (the capybara Hydrochoerus hydrochaeris Linnaeus, 1766; the Neotropical river otter Lontra longicaudis Olfers, 1818; G. cuja and L. wiedii) where found only in forest sites. By contrast, L. europaeus was the only species that was not recorded in forest sites and was recorded in plantation and grassland sites. Although there were four more species (O. geoffroyi, E. sexcinctus, $P$. cancrivorus, and D. albiventris), in plantation than in grassland, there was no significant difference in species composition between these two habitats (MRPP, $\mathrm{A}=-0.0006, \mathrm{p}=0.43$ ).

Many habitat and landscape variables were strongly correlated with axis 1 (Fig. 3). Vertical structure index $(r=0.581)$, percentage of trees $(r=0.626)$, percentage of leaves $(r=0.661)$, canopy cover $(r=0.723)$, stand basal area $(r=0.716)$, tree species diversity $(r=0.666)$, width of water course $(r=0.574)$ and percentage of forest at $0.1 \mathrm{~km}(\mathrm{r}=0.669)$ separated forest sites from plantation and grassland sites. By contrast, percentage of grass $(\mathrm{r}=-0.589)$, maximum temperature $(\mathrm{r}=-0.587)$ and percentage of grassland at $0.1 \mathrm{~km}(\mathrm{r}=-0.551)$ separated grassland from plantation and forest.

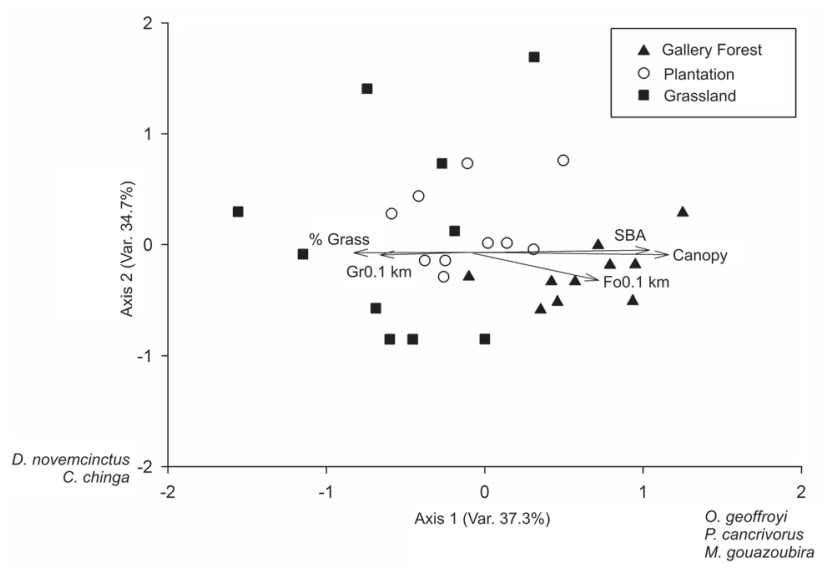

Figure 3. Nonmetric Multidimensional Scaling (NMS) ordination based on mammal species composition. Vectors represent the direction and strength of the most important environmental variables. Environmental variables: (\%Grass) percentage of grass, (Canopy) canopy cover, (SBA) Stand Basal Area, (Fo0.1 Km) percentage of forest at $0.1 \mathrm{~km},(\mathrm{Gr} 0 . \mathrm{IKm})$ percentage of grassland at $0.1 \mathrm{~km}$. The species outside the ordination plot represent the species with the highest correlation values with the corresponding axis that influence the ordination.

\section{DISCUSSION}

Thirteen native and two exotic medium and large mammal species were detected in the study area. All species, except L. wiedii, were expected to occur in the area (Gonzalez 2001). In contrast, some species that had been observed in the de- 
partment of Rivera were not detected (GonZALEz 2001). Some of these species are listed as extinct in the country (the jaguar Pantera onca Linnaeus, 1758; and the puma Puma concolor Linnaeus, 1771). Other species have only been observed a few times in other locations in Rivera (the southern tamandua Tamandua tetradactyla Linnaeus, 1758; and the greater nakedtailed armadillo Cabassous tatouay Desmarest, 1804) and others are more common, e.g. the brown-nosed coati Nasua nasua Linnaeus, 1766 (Jessica Castro-Prieto pers. comm.). Species such as the lutrine opossum Lutreolina crassicaudata Desmarest, 1804 and the coypu Myocastor coypus Molina, 1782 were not recorded because their typical habitats (e.g. wetlands, and lagoons) were not surveyed. Probably due to its arboreal habits, the Paraguayan hairy dwarf porcupine Sphiggurus spinosus F. Cuvier, 1823 was not recorded. However, one individual was previously observed in one of the study sites. One track of the ocelot Leopardus pardalis Linnaeus, 1758 was found at one of the forest sites (F1) during a rapid survey in 2006, but the species was not recorded in the present study, probably due to its low abundance in the region. The only widely distributed and common species in the country which was not recorded in our study was the southern long-nosed armadillo Dasypus hybridus Desmarest, 1804, a grassland specialist armadillo.

Our results demonstrate that $C$. thous, D. novemcinctus and M. gouazoubira, the most abundant species in our data, can use transformed habitats. These are forest species with generalist habits which can use cultivated lands near forest (PINDER \& Leewenberg 1997). They were found in forest, plantation and grassland sites. These species are also abundant in agricultural areas in the state of São Paulo, Brazil where they were recorded in a variety of habitats (e.g. sugar cane plantations, forest fragments, Eucalyptus plantation and grassland) (DotTa \& Verdade 2007). In the Cerrado, C. thous was more common in Eucalyptus plantations than in native forest (LyRA-Jorge et al. 2008a). The least abundant species in our results were $L$. wiedii and $G$. cuja. Leopardus wiedii is a rare small feline found exclusively in forest and has its southern distribution limit in Uruguay (OLVEIRA 1998). Although G. cuja is a generalist species capable of using disturbed areas such as plantations (DotTA \& VERDADE 2007), it was only recorded by tracks in two gallery forests in our study. This species may not have been detected by camera traps because of its small size (LyRA-Jorge et al. 2008b).

One of the main conclusions of this study is that the mammal community within a plantation-dominated matrix is characterized by a predominance of generalist species, or species that are capable of using transformed habitats (Almeida et al. 2008, Farias \& KitTle 2008, DotTa \& Verdade 2007, Manfredi et al. 2006, Pinder \& LeEwenberg 1997), and a low proportion of specialist species. Many forest species avoid open areas such as grassland, but they can be detected traversing them while moving between forest sites. Additionally, some grassland species can explore forest looking for food (CÁCEREs 2004, GoNZALEZ 2001); however, carnivore species, which have large home ranges become more generalist in an altered landscape and are not restricted to native forest (LyRA-Jorge et al. 2008a).

Another important conclusion is that transformed habitats such as Eucalyptus plantations can have both positive and negative effects on medium and large mammals. Plantations positively affect mammals by increasing the local distribution of some forest species that avoid grassland. Six of the ten generalist forest species have increased their local distribution to include plantation which were previously grassland, habitats rarely used by forest species. Cerdocyon thous and D. novemcinctus have broad food and habitat requirements and they increase their local distribution by using plantations. By contrast, plantations are negatively affecting the presence and possibly the local distribution of species such as $D$. hybridus, a very common grassland species that was not detected in this study, presumably due to the loss and fragmentation of its primary habitat, grassland.

Mammal species richness differed among the three habitats types (forest, plantation and grassland). This result contrasts with the results of another study near São Paulo (DOTTA \& VERDADE 2007) where mammal species richness did not differ among the same three habitats plus sugar cane plantations. Species composition between native forest and plantation and between forest and grassland was different. Similar results were found in other studies (DOTTA \& VERDADE 2007), which highlights the importance of forest as a primary habitat and the importance of its conservation within a matrix of exotic tree plantations. Species composition was not significantly different between plantation and grassland although four more mammal species (D. albiventris, E. sexcinctus, O. geoffrogyi, and P. cancrivorous) were recorded in plantation. This lack of a statistically significantly difference can be explained by the fact that these species were only recorded once in plantation sites, which reduces the effect of these species in determining differences in species composition. This result suggests that mammal species use plantation differently, and that these four mammal species probably use plantation as corridors, spending less time in it, which would explain the fact that they have been poorly recorded.

In our study the differences in species richness and composition among forest, plantation and grassland can be explained by differences in habitat and landscape variables among the three habitat types. Most of the habitat variables that are correlated with mammal ordination are characteristics of forest sites (e.g. tree diversity and canopy cover) which highlight the importance of gallery forest in maintaining mammal community. Furthermore, some species (e.g. H. hydrochaeris, L. longicaudis) were recorded only in gallery forest, which demonstrates its importance as primary habitat. In addition, the proportion of forest and grassland in the landscape at $0.1 \mathrm{~km}$ were correlated with mammal species richness and composition. These findings emphasize the importance of maintaining areas of forest and grassland in this plantation matrix to ensure the conservation of the mammal community. Forest and grassland areas are crucial for the maintenance of the entire mammal community because most 
of the species use these habitats as primary or secondary habitat. Most studies emphasize the importance of forest (JoHnson et al. 1999, LeEs \& Peres 2008), but the multi-scale approach demonstrated also the importance of temperate grassland, one of the most threatened ecosystems worldwide, as a valuable resource for the mammal community.

\section{Conservation activities}

From our results two conservation measures can be proposed to landowners such as forestry companies and ranchers to conserve the mammal community outside of protected areas. The most important measure is to protect the small area of gallery forest by reducing logging and cattle grazing. This will help maintain habitat variables such as tree species richness, vertical structure and canopy cover, important factors determining mammal presence. The other important conservation measures would be to increase grassland buffer zones between plantation and forest. Presently grassland buffer zones between gallery forest and plantation are only $20 \mathrm{~m}$ wide. This buffer zone is created specifically to protect water quality (FSC 1996) and not grassland or forest habitats. In order to foster mammal conservation, however, this grassland buffer zone needs to be larger, in order to reduce the impact of plantation management procedures (e.g. fertilizing, pruning, harvesting) on forest species. Although, the effect of the proximity to plantations on forest mammals was not directly assessed in our study, we believe that alteration of neighboring habitats is likely to alter the gallery forest community. In addition, buffer zones need to be larger to allow the persistence of grassland species within the plantation matrix. The conservation of mammals outside protected areas relies on the continued effort to understand how human activities affect mammal community, and how management efforts can reduce the negative impact of these activities.

\section{ACKNOWLEDGMENTS}

We thank the Andrade Núñez family specially to Hugo Andrade, the Diez Castro family, Diana Pérez, Magaly Burgues, Diego Caballero and María N. Merentiel for their assistance in the field, Ivan Grela and Elman Sánchez for plant species identification, Diego Queirolo and Graziela Dotta for track species identification, Carlos Zambrana for help with data analysis, and Martha Bonilla for comments in the manuscript. This study was supported by Rufford Small Grant Foundation, Red de Macro Universidades de América Latina y el Caribe and Santander Bank, University of Puerto Rico (DEGI, Crest-Catec and Biology Graduate Program), COFUSA forestry company, and the National Science Foundation (0709598).

\section{LITERATURE CITED}

Almeida, A.; C. Torquetti \& S. Talamoni. 2008. Use of space by neotropical marsupial Didelphis albiventris (Didelphimorphia: Didelphidae) in an urban forest fragment. Revista Brasileira de Zoologia 25 (2): 214-219.
ANDRÉN, H. 1994. Effects of habitat fragmentation on birds and mammals in landscapes with different proportions of suitable habitat: A review. Oikos 71 (3): 355-366.

Atauri, J. \& J. Lucio. 2001. The role of landscape structure in species richness distribution of birds, amphibians, reptiles and lepidopterans in Mediterranean landscapes. Landscape Ecology 16: 147-159.

Attum, O.; Y. Lee; J. Roe \& B. Kingsbury. 2008. Wetland complexes and upland-wetland linkages: landscape effects on the distribution of rare and common wetland reptiles. Journal of Zoology 275: 245-251.

CÁCEREs, N. 2004. Occurrence of C. chinga (Molina) (Mammalia, Carnivora, Mustelidae) and other terrestrial mammals in the Serra do Mar, Paraná, Brazil. Revista Brasileira de Zoologia 21 (3): 577-579.

Cardoso da Silva, J. \& J. Bates. 2002. Biogeographic Patterns and Conservation in the South American Cerrado: A Tropical Savanna Hotspot. BioScience 52 (3): 225-234.

COFUSA. 2006. Resumen del Plan de Manejo. Available on line at: http://www.cofusa.com.uy [Accessed: 21.V.2009].

Colwell, R.K. 2005. EstimateS: Statistical estimation of species richness and shared species from samples. Version 7.5. User's Guide and application. Available online at: http:// purl.oclc.org/estimates [Accessed: 10.I.2009].

Cracco, M.; L. García; E. González; L. Rodríguez \& A. Quintallán. 2005. Importancia global de la biodiversidad de Uruguay. Borrador para el Proyecto Fortalecimiento de las Capacidades para la Implementación del Sistema Nacional de Áreas Protegidas de Uruguay. Montevideo. DINAMA/ PNUD/GEF, 25p.

Daily, G.; G. Ceballos; J. Pacheco; G. Suzán \& A. Sánchez-Azofeifa. 2003. Countryside biogeography of Neotropical mammals: landscapes of Costa Rica. Conservation Biology 17 (6): 1814-1826.

Dauber, J.; M. Hirsch; D. Simmering; R. Waldhardt; A. Otte \& V. Wolters. 2003. Landscape structure as an indicator of biodiversity: matrix effects on species richness. Agriculture, Ecosystems and Environment 98: 321-329.

DotтA, G. \& L. Verdade. 2007. Trophic categories in a mammal assemblage: diversity in an agricultural landscape. Biota Neotropical 7 (2): 287-292.

FAHRIG, L. 2003. Effects of habitat fragmentation on biodiversity. Annual Reviews of Ecology, Evolution, and Systematics 34: 487-515.

Farias, A. \& M. Kittlen. 2008. Small-scale spatial variability in the diet of pampas foxes (Pseudalopex gymnocercus) and human-induced changes in prey base. Ecological Research 23: 543-550.

Foley, J.; R. DeFries; G. Asner; C. Barford; G. Bonan; S. Carpenter; F. Stuart Chapin; M. Coe; G. Daily; H. Gibbs; J. Helkowski; T. Holloway; E. Howard; C. Kucharik; C. Monfreda; J. Patz; C. Prentice; N. RamankutTy \& P. SNYder. 2005. Global consequence of land use. Science 309: 570-574. 
Forman, R. T. T. 1999. Land Mosaics. The ecology of landscapes and regions. New York, Cambridge University Press, 632p.

FSC. 1996. National Forest Stewardship Standard for Finland. Available online at: http://finland.fsc.org [Accessed: 15.V.2009].

GEARY, T. F. 2001. Afforestation in Uruguay. Study of a Changing Landscape. Journal of Forestry 99 (7): 35-39.

Gorresen, P.; M. WilLing \& R. Strauss. 2005. Multivariate analysis of scale-dependent associations between bats and landscape structure. Ecological Applications 15 (6): 2126-2136.

Gotelli, N. \& R. Colwell. 2001. Quantifiying biodiversity: procedures and pitfalls in the measurement and comparison of species richness. Ecology Letters 4: 379-391.

Gotmark, F.; T. von Proschwitz \& N. Franc. 2008. Are small sedentary species affected by habitat fragmentation? Local vs. landscape factors predicting species richness and composition of land molluscs in Swedish conservation forest. Journal of Biogeography 35: 1062-1076.

GonzÁlez, E.M. 2001. Guía de campo de los mamíferos de Uruguay. Introducción al estudio de los mamíferos. Montevideo, Vida Silvestre, 340p.

Habeeb, R.; J. Trebilco; S. Wotherspoon \& C. Johnson. 2005. Determining natural scales of ecological systems. Ecological Monographs 75 (4): 467-487.

Habeeb, R.; C. Johnson; S. Wotherspoon \& P. Mumby. 2007. Optimal scales to observe habitat dynamics: a coral reef example. Ecological Applications 17 (3): 641-647.

Holland, J.; D. Bert \& L. Fahrig. 2004. Determining the spatial scale of species response to habitat. BioScience 53 (3): 227 233.

Holm, S. 1979. A simple sequentially rejective multiple test procedure. Scandinavian Journal of Statistics 6: 65-70.

IUCN. 2008. 2008 IUCN Red List of Threatened Species. Available on line at: http://www.iucnredlist.org [Accessed: 15.V.2009].

Johnson, M.A.; P.M. Saraiva \& D. Coelho. 1999. The role of gallery forests in the distribution of Cerrado mammals. Revista Brasileira de Biologia 59 (3): 421-427.

Karlson, R. \& H. Cornell. 1998. Scale dependent variation in local versus regional effects on coral species richness. Ecological Monographs 68 (2): 259-274.

KeitT, T.H.; D.L. Urban \& B.T. Milne. 1997. Detecting critical scales in fragmented landscapes. Conservation Ecology (on line) 1(1): 4. Available on line at: http://www.consecol.org/ vol1/iss1/art4 [Accessed: 19.XII.2008].

Lambin, E.; B. Turner; H. Geist; S. Agbola; A. Angelsen; J. Bruce; O. Coomes; R. Dirzo; G. Fischer; C. Folke; P. George; K. Homewood; J. Imbernon; R. Leemans; X. Li; E. Moran; M. Mortimore; P. Ramakrishnan; J. Richards; H. Skanes, W. Steffen, G. Stone, U. Svedin, T. Veldkamp, C. Vogel \& J. Xu. 2001. The cause of land-use and land-cover change: moving beyond the myths. Global Environmental Change 11 (4): 261-269.

LeEs, A. \& C. Peres. 2008. Conservation value of remnant riparian forest corridors of varying quality for Amazonian birds and mammals. Conservation Biology 22 (2): 439-449.

Lindenmayer, D.; R. Cunningham \& M. Pope. 1999. A large scale "experiment" to examine the effects of landscape context and habitat fragmentation on mammals. Biological Conservation 88: 387-403.

Lyra-Jorge, M.; G. Ciocheti \& R. Pivello. 2008a. Carnivore mammals in a fragmented landscape in northeast of Sao Paulo, Brazil. Biodiversity Conservation 17: 1573-1580.

Lyra-Jorge, M.; G. Ciocheti; R. Pivello \& S. Tadeu. 2008b. Comparing methods for sampling large and medium-size mammals: camera traps and track plots. European Journal of Wildlife Research 54 (4): 739-744.

Manfredi, C.; L. Soler; M. Lucherini \& E. Casanave. 2006. Home range and habitat use by Geoffroy's cat (Oncifelis geoffroyi) in a wet grassland in Argentina. Journal of Zoology 268: 381-387.

McCune, B. \& M.J. Mefford. 1999. PC-ORD. Multivariate Analysis of Ecological Data. Version 5.0. Glededen Beach, MjM Software.

MGAP. 2005. Boletín Forestal.2005. Dirección General Forestal. Available on line at: htpp://www.mgap.gub.uy/ Forestal/Boletín2005.pdf [Accessed: 11.III.2009].

Mikusinski, G. \& P. Angelstam. 2004. Ocurrence of mammals and birds with different ecological characteristics in relation to forest cover in Europe- do macroecological data make sense? Ecological Bulletins 51: 265-275.

Millennium Ecosystem Assessment. 2005. Ecosystems and human well-being: a framework for assessment. Washington. Island Press, 266p.

OlfF, H. \& M. Ritchie. 2002. Fragmented nature: consequences for biodiversity. Landscape and Urban Planning 58 (2-4): 83-92.

OlveIra, T. 1998. Leopardus wiedii. Mammalian Species 579: 1-6.

Pinder, L. \& F. Leeuwenberg. 1997. Veado-catingueiro, p. 59-68. In: J.M.B. DuARTE (Ed.). Biologia e conservação de Cervídeos sul-americanos: Blastocerus, Ozotoceros e Mazama. Jaboticabal, Funep.

R Development Core Team. 2009.R: A language and environment for statistical computing. R Foundation for Statistical Computing, Vienna, Austria. ISBN 3-900051-07-0. Available on line at: http://www.R-project.org [Accessed: 15.III.2009].

Reidsma, P.; T. Tekelenburg; M. van den Berg \& Alkemade, R. 2006. Impacts of land use change on Biodiversity in the European Union. Agriculture, Ecosystems and Environment 114: 86-102.

Rhodes, J.; C. McAlpine; A. Zuur; G. Smith \& E. Ieno. 2009. GLMM applied on the spatial distribution of koalas in a fragmented landscape, p. 469-492. In: A. Zuur; E. Ieno; N. Walker; A. Saveliev \& G. Smith (Eds). Mixed Effects Models and Extensions in Ecology with R. New York. Springer.

Sala, O.; F. Chapin III; J. Armesto; E. Berlow; J. Bloomfield; R. Dirzo; E. Huber-SAnwald; L. Huenneke; R. Jackson; A. Kinzig; R. 
Leemans; T. Lodge; H. Mooney; M. Oesterheld; N. LeRoy; T. Sykes; B. Walker; M. Walker \& D. Wall. 2000. Global Biodiversity Scenarios for the Year 2100. Science 287: 17701774.

Sala, O.; A. Austin \& L. Vivanco. 2001. Temperate grassland and shrubland ecosystems, 5. p 627-635. In: S. A. Levin (Ed). Encyclopedia of Biodiversity. San Diego. Academic Press.

Sanderson, J. 2004. Tropical Ecology, Assessment and Monitoring Initiative. Camera Phototrapping Monitoring protocol. Version 2.0. Available on line at: http:// costarica.jsd.claremont.edu/pdf/TEAMCameraTraps-PT-EN2.0.pdf [Accessed: 6.X.2008].

TORres, J.M. \& A. Fossati. 2004. Estudio de tendencias y perspectivas del sector forestal en América Latina. Documen- to de Trabajo. Informe Nacional Uruguay. Roma. FAO. Available on line at: http://www.fao.org/docrep/007/j2807s/ j2807s00.HTM [Accessed: 4.XII.2008]

Turner, M.; R. Gardner \& R. O'NeILl. 2001. Landscape ecology in theory and practice: patterns and processes. New York, Springer-Verlag, 401p.

Vandermeer, J. \& R. Carvajal. 2001. Metapopulation dynamics and the quality of the matrix. The American Naturalist 158 (3): 211-220.

Zabala, J.; I. Zuberogoita \& J. Martinez-Climent. 2005. Site and landscapes features ruling the habitat use and occupancy of the polecat (Mustela putorius) in a low density area: a multiscale approach. European Journal of Wildlife Research 51 (3): 157-162.

Submitted: 19.XI.2009; Accepted: 19.IX.2010.

Editorial responsibility: Heraldo L. de Vasconcelos 